\title{
Autunite-Group Minerals and Their Paragenesis from the Sheared Granite of Gabal El Sela, South Eastern Desert, Egypt
}

\author{
Ehab K. Abu Zeid \\ Nuclear Material Authority, Cairo, Egypt \\ Email: ehab_abuzeid@yahoo.com
}

How to cite this paper: Zeid, E.K.A. (2020) Autunite-Group Minerals and Their Paragenesis from the Sheared Granite of Gabal El Sela, South Eastern Desert, Egypt. Open Journal of Geology, 10, 703-725. https://doi.org/10.4236/ojg.2020.106031

Received: April 27, 2020

Accepted: June 27, 2020

Published: June 30, 2020

Copyright $\odot 2020$ by author(s) and Scientific Research Publishing Inc. This work is licensed under the Creative Commons Attribution-NonCommercial International License (CC BY-NC 4.0). http://creativecommons.org/licenses/by-nc/4.0/ (c) (i) (8) Open Access

\begin{abstract}
G. El Sela is located in the Southern Eastern Desert of Egypt cropping as two parts, occupied by monzogranites that were categorized as biotite granite, muscovite granite and two mica granites. The northern part is more significant according its high concentrations of uranium that controlled by complicated structure regime; faulting, infrastructures and shearing are the most common structural criteria of this part. The Egyptian Nuclear Materials Authority (NMA) mined this part to produce the uranium ore. The previous mineralogical studies indicated that this granite was dominated by primary uranium minerals (pitchblende and coffinite) and secondary minerals belong to the autunite group (autunite, metautunite, phurcalite) in addition to uranophane. In the present work, petrographic and mineralogical studies are applied for the granites using the polarized and stereo microscopes and followed by electron microscope and XRD. The result of the microscopic examinations revealed the tectonic regime controlling the radioactivity and recognized the sodic autunite (meta-natroautunite) beside the pre-mentioned autunite group minerals completing the paragenetic sequrnce of these minerals. In this study, it is concluded that the sheared biotite granite is monzogranite originated during the episode of the continental plate collision (syncollision). The study finished to presence of two main types of the alteration corresponding to the two high levels of radioactivity (moderate and anomalous). The first is the thermal alteration (saussiritization, sericitization, kaolinization, silicification and hematization) and the second is the chemical transformation (oxidation, dehydration, ion substitutions and confusion) responsible for formation of the secondary uranium minerals. The temperature needed for the thermal alteration is sourced by the hydrothermal solutions, while the temperature needed for the uranium minerals transformation may be generated during the episode of the continental plate collision (syncollision). Paragenesis of these minerals indicates that they represent a series of uranyl phosphate min-
\end{abstract}


erals (autunite group) with paragenetic sequence starting by autunite (calcic uranyl phosphate) and ends by meta-natroautunite (sodic uranyl phosphate). An advanced process of dehydration accompanies the process of mineral transformation from autunite to meta-natroautunite leading to formation of the anhydrous uranyl mineral (phurcalite) formed by oxidation and dehydration of autunite. Meta-autunite is recorded as a transitional mineral composed of sodic-calcic uranyl phosphate. Uranophane is created by thermal confusion of autunite with the silica.

\section{Keywords}

Autunite-Group, Paragenesis, Thermal Alteration, Chemical Alteration, Confusion

\section{Introduction}

Gabal El Sela is located south the Eastern Desert between latitudes $22^{\circ} 14^{\prime}$ to $22^{\circ} 18^{\prime}$ and longitudes $36^{\circ} 12^{\prime}$ to $36^{\circ} 16^{\prime}$, west of Abu Ramad city by about $25 \mathrm{~km}$ covering about $73 \mathrm{Km}^{2}$ (Figure 1). The northern part represents the main shearing zone that was considered as good hostile for uranium-minerals and significant targets for uranium mining where the Egyptian Nuclear Materials Authority (NMA) mined for production of uranium ore. Mineralogy of El Sela granite was studied by many authors clarifying prevalence of the secondary uranium minerals besides the primary uranium minerals in this granite.

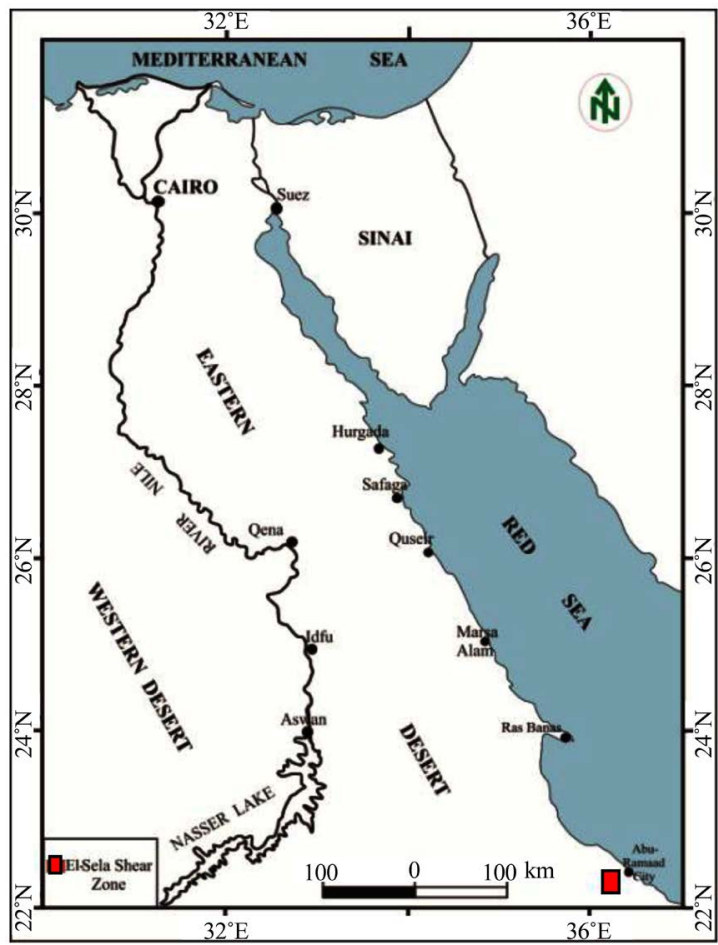

Figure 1. Location map of G. El Sela. South Eastern Desert, Egypt. 
Ali (2011) [1] studied the structures of the area of G. El Sela and postulated a succession of tectonic events that controlled the structures of the mineralized zones. He suggested four tectonic episodes that affected the study area: (E1) folding-thrusting episode, (E2) an upright folding episode associated with compression and shortening to the ENE-WSW direction, (E3) post-tectonic granitic intrusion episode and (E4) fracturing, faulting, and post-granitic dike extrusion episode causing different faults that took place after cratonization.

Ali and Lentz (2011) [2] studied El Sela granite and stated that U-mineralization occurred as the product of the hydrothermal processes; it includes fine inclusion of the primary U-minerals (uraninite with low Th contents). They suggested that the mineralizing event was post magmatic with later hydrothermal alteration and local remobilization of the high-field strength elements. They studied the monazite crystals under EPMA technique and recorded late-orogeny age about $644 \pm 6 \mathrm{Ma}$ for El Sela granite.

Mira, and Ibrahim, (2011) [3] concluded that the mineralogical characteristics of the studied weathered rocks indicate that the main geochemical driving forces have been the redox and super genic enrichment processes. The coexistence of the tetravalent uranium minerals such as pitchblende and coffinite with the hexavalent minerals uranophane, autunite and chrysocolla supports the transitional redox environment, where oxidizing and reducing conditions are predominant. Hence, the primary minerals were formed biogenically through the biomineralization process.

Fawzy (2012) [4] indicated that uranium minerals in El Sela granite are secondary uranium minerals present as an array of bright yellow, orange, green colors increasing with decreasing the grain size. They occur as earthy or powdery materials or as fine, delicate, needle-like or platy, flake-like crystals. The most common uranium-minerals are uranophane, phurcalite, autunite and meta-autunite.

Shalan (2012) [5] stated that the secondary uranium minerals in G. El Sela present as uranophane and beta-uranophane associated with autunite and meta-autunite occurring as thin flakes adsorbed upon the sheeted kaolinite accompanying the main shear zone.

The Egyptian Nuclear Materials Authority (2013) [6] is interested in production of uranium ore from the sheared granite of G. El Sela. They recorded the pitchblende uranophane and uranothorite as the main radioactive minerals besides the other radioelements-bearing minerals as xenotime, monazite and zircon.

Anwar (2015) [7] recognized secondary uranium-minerals as lead-metautunite and phurcalite where lead is the main constituent referring to enrichment of lead in El Sela granites. In this study the author gave attention to the light fraction beside the heavy fraction, that separated by bromoform, as source of radioactive minerals (autunite) indicating that, clay minerals play an important role as natural adsorbent to heavy and nuclear metals such as vanadium and uranium. Kaolinite is the most common alteration product associated with secondary ura- 
nium minerals as low-temperature alteration of feldspars, muscovite and other Al-rich silicates. Accordingly, the high radioactivity of the light fraction in El Sela sheared granite is mainly attributed to the adsorption of uranium onto kaolinite and altered feldspars. Such features clearly indicate the percolation of late magmatic, highly fractionated melt associated with high potential fluid phases in the shear zone led to the simultaneous enrichment of uranium, thorium. $\mathrm{He}$ added that the high radioactivity of the light fraction is mainly attributed to presence of the secondary uranium minerals coating the light minerals and most probably to the adsorption of hexavalent uranium onto the clay minerals (kaolinite). This mode of occurrence of the uranium must be considered during mineral processing whether by physical or direct hydrometallurgical treatments.

Sadek (2017) [8] studied the genesis of the secondary uranium minerals and stated that they are mainly coffinite, uranophane, autonite and betafite. His fluid inclusion studies indicated that mineralizing fluids were transported mainly through two stages; the first was represented by $\mathrm{CO}_{2}$ rich, higher temperature (up to $259^{\circ} \mathrm{C}$ ), and high salinity (up to $29 \mathrm{Wt} \% \mathrm{NaCl}$ equ.), suggesting that uranium was transported mainly in the form of uranyl-monocarbonate complex $\left(\mathrm{UO}_{2} \mathrm{CO}_{3}\right)$. Secondary uranium mineralization resulted from aqueous mineralized fluids with the temperature gradient away from the heat source (from $198^{\circ} \mathrm{C}$ to $209^{\circ} \mathrm{C}$ ). The fluid/rock interaction and the salinity changes from 15 to $24(\mathrm{NaCl} \mathrm{Wt} \%$.) due to the mixing of the hydrothermal fluids with shallow meteoric water that related to fracture systems during post magmatic stage lead to change in $\mathrm{pH}$ value and consequently precipitation of secondary uranium mineralization.

The present work aims to establish the petrographic features for some of the autunite-group minerals and the petrogenetic relations among these minerals. Also, looking for new members for this group to shed light on the paragenetic sequence and the diagenetic processes responsible for generating these minerals. Tectonic regime combined with the description of alteration processes may help to solve the mystery of presence of two separate levels of radioactivity (high and anomalous) in G. El Sela.

\section{Materials and Methods}

The granitic samples picked from the area of study, prepared as thin sections and studied by the transmitted polarized microscope (Olympus BX53). The anomalous samples crushed, stored in plastic containers for 21 days and the radioelements concentrations measured radiometrically by lab technique known as Bicron Scintillation Detector NaI (T1) $76 \times 76 \mathrm{~mm}$ with multichannel analyzer (NMA). The crushed samples sieved to grain size between +63 and $-500 \mathrm{Um}$ and the heavy minerals separated by bromoform. The uranium minerals picked and studied in the different labs of Egyptian Nuclear Materials Authority (NMA). They are examined by the stereomicroscope and recognized by Phillips XRD equipment (pw/3710). Their compositions confirmed by using the electron scanning microscope (ESEM) with energy dispersive $\mathrm{x}$-ray unit (EDX) model XI 30 
with tungsten filament.

\section{Geological Outlines}

G. El Sela is bounded by G. Qash Amir from the western side, W. Eshmahi from the north and W. Yoidar from the south (Figure 2). Geological studies indicated that it is a granitic pluton characterized by grayish pink color with obvious flakes of mica cropping as two parts (Figure 3).

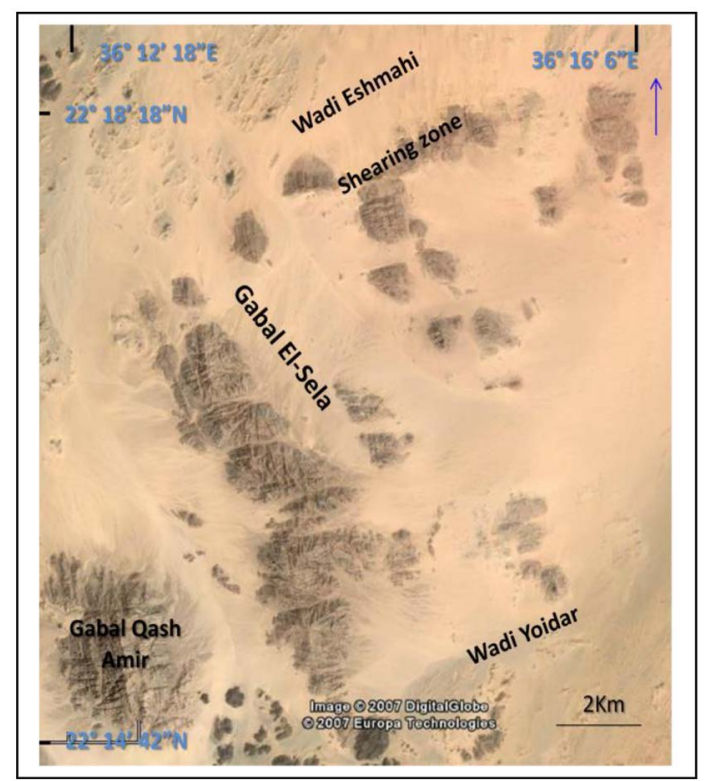

Figure 2. Land Sat image for G. El Sela. South Eastern Desert, Egypt.

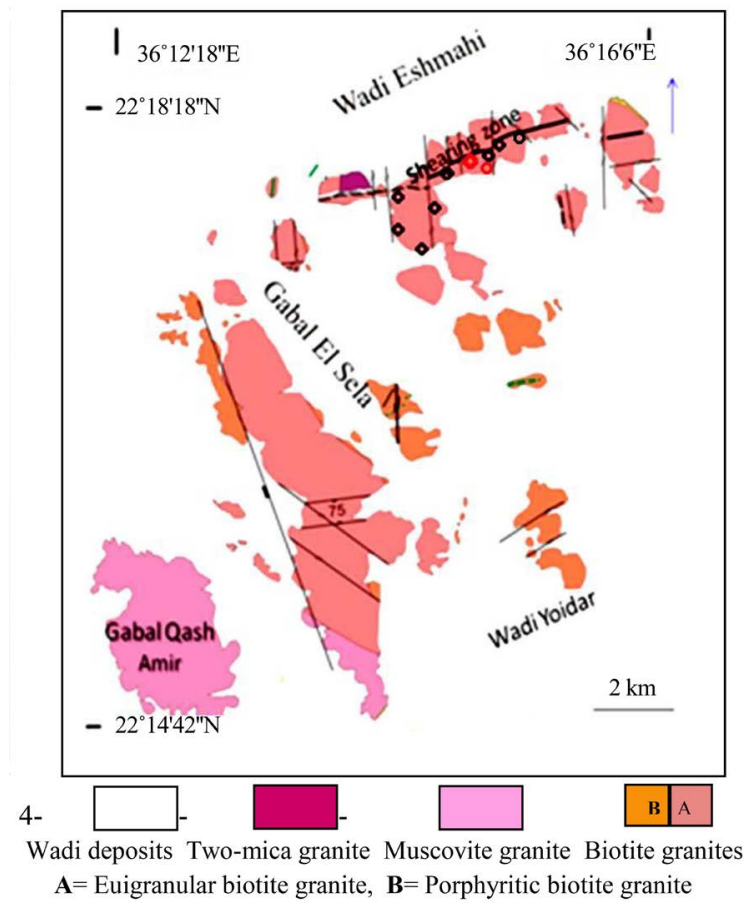

Figure 3. Geologic map of G. El Sela (NMA, 2013). 
The southern part crops as elongated body extending NNW-SSE, dissected by several faults and described as biotite granite and muscovite granite; the biotite granite distinguished to euigranular granite (A) and porphyritic granite with phenocrysts of the feldspars (B). The northern part described as biotite granite extending ENE-WSW and divided by major fault that superimposed by parallel $\mathrm{N}$-S fault set (Figure 4).

The sheared biotite granite of the northern part is the aim of study (Figure 5), where the major fault trends ENE-WSW (Figure 6). It is intensively sheared granite, dissected by many faults in different directions (F1 and F2) in addition to the parallel fault set (Figure 7). The rock itself is highly fractured allowing the hydrothermal solution to enrich the rock by iron oxides and uranium concentrations. The main shearing zone is mined by the Egyptian Nuclear Materials Authority to produce the uranium ore from two main trenches cross-cutting the main shear zone in El Sela granite (Figure 8).

\section{Microscopic Investigation}

The thin sections of the ten samples are examined by the polarized microscope to identify the composition of El Sela granite. The composition analyzed and plotted on the ternary diagram of Streckeisen (1976) [9] for six samples to deduce its type (Loiselle \& Wones, 1979) [10] and probable tectonic setting by using the fields of tectonism that established by Maniar and Piccoli (1989) [11].

\subsection{Petrographic Features}

El Sela sheared granite is medium grained granite composed mainly of Plagioclase, alkali feldspars, quartz and mica minerals; characterized by grayish pink color and equigranular texture with grain size from 2 to $3 \mathrm{~mm}$ length. Plagioclase is the main feldspar occurring as euhedral crystals of oligoclase $\left(\operatorname{An}_{12-18}\right)$ with lamellar twining; occasionally fractured and altered (Figure 9). The more calcic crystals of plagioclase are saussiritized and muscovitized, while the more

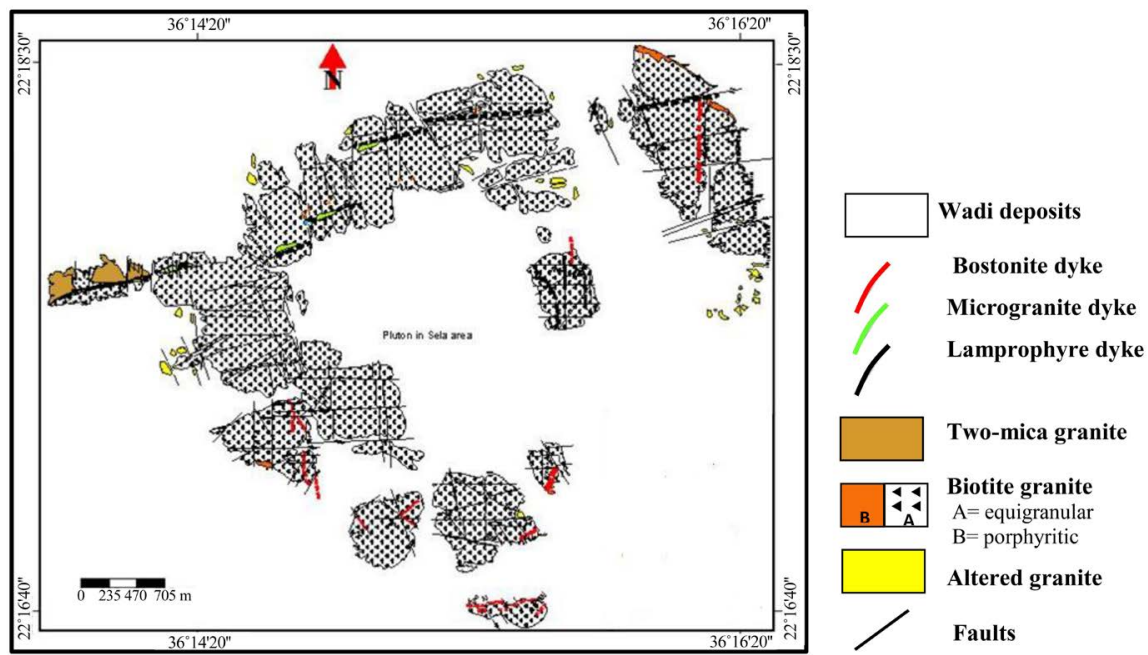

Figure 4. Geologic map for the northern part of G. El Sela (modified after Ali, 2011). 


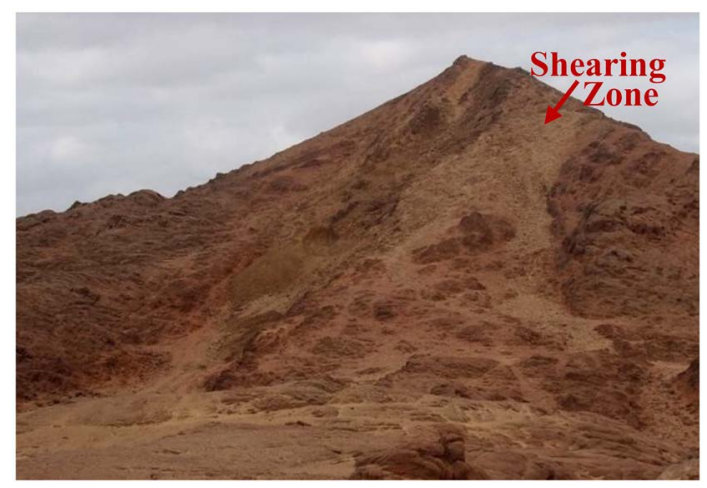

Figure 5. Panoramic view for the studied shearing Zone, G. El Sela.

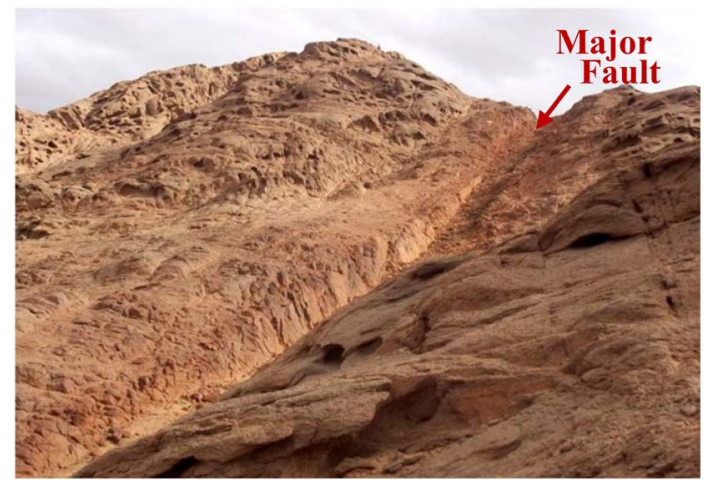

Figure 6. The major fault trending ENE-WSW, G. El Sela.

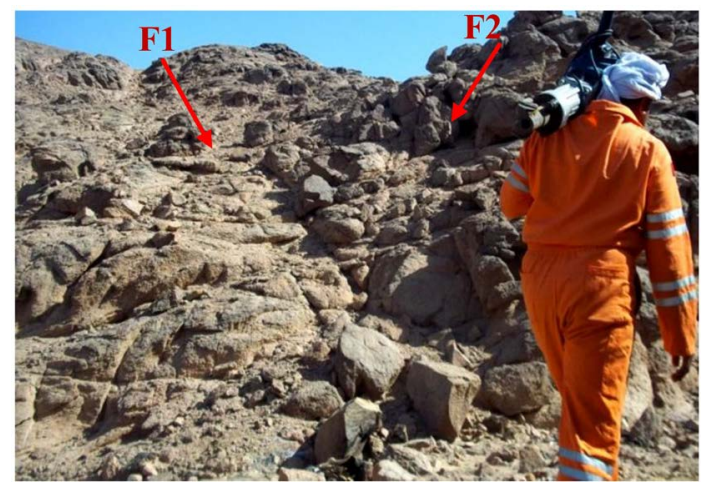

Figure 7. Two minor faults (F1 \& F2) in the sheared. Granite, G. El Sela.

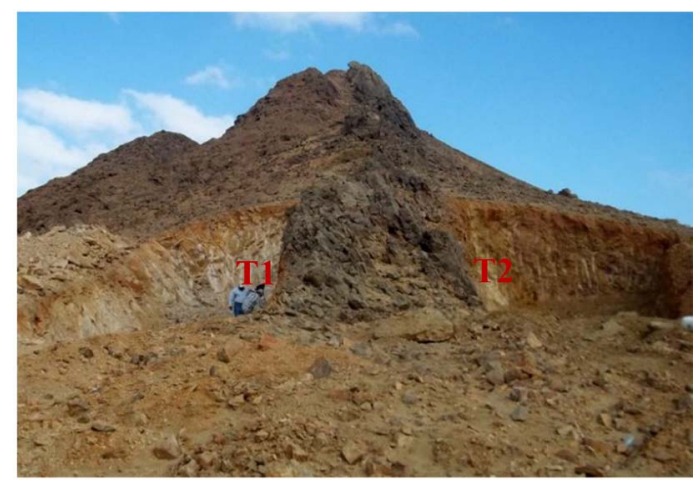

Figure 8. Two trenches (T1 \& T2) for uranium ore. G. El Sela. 


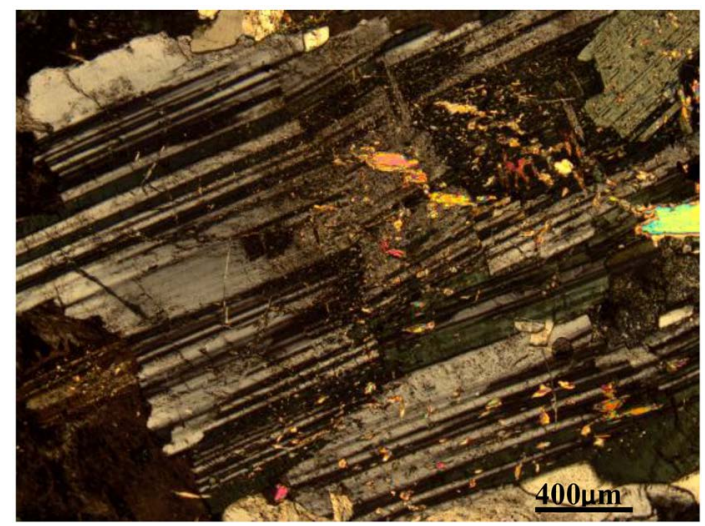

Figure 9. Photomicrograph for El Sela biotite granite showing: A fractured crystal of plagioclase with dislocation and partial muscovitization, CN.

sodic crystals are molten and digested by the alkali feldspars exhibiting intermittent lamellar twining (Figure 10). Alkali feldspars present as euhedral crystals of perthite and antiperthite mostly digest the more sodic plagioclase (see Figure 10) or corrode the earlier minerals such as the muscovite (Figure 11). Quartz is present as primary euhedral crystals occupying about $35.4 \%$ of the rock. The mica minerals represented by muscovite and biotite occupying about $2.9 \%$ of the rock. Muscovite present as primary flakes is corroded by the feldspars (see Figure 11) and as secondary flakes after biotite that characterized by moderate pleochroism from pale brown to brown (Figure 12). In the highly altered samples, quartz is enriched by silicification of the feldspars, where they are completely saussiritized (Figure 13) and sericitized (Figure 14).

Accessory minerals are mainly zircon in addition to the radioactive minerals represented by uranophane, autunite and metautunite, Zircon faintly metamectized and fractured by effect of the radioactive damage (Figure 15). Uranophane presents associating quartz and tightly related to the process of reworked silica (Figure 16). Autunite occurs as tabular crystals with rectangular outlines characterized by low relief and lemon yellow color; pleochroism is visible ( $\mathrm{X}=$ colorless to pale yellow and $\mathrm{Z}=\mathrm{Y}=$ yellow to dark yellow) (Figure 17). Its interference colors are masked by the yellow color of autunite (Figure 18). Metautunite presents as well-formed crystals with greenish yellow color coated by iron oxides and characterized by cracks (Figure 19) and grey and yellow interference colors (Figure 20). Few crystals of violet fluorite separated from the samples that picked from the shearing zone.

\subsection{Type of El Sela Granite}

El Sela sheared granite characterized by high content of quartz ranging from $34.5 \%$ to $36.5 \%$ of the whole rock composition. The altered samples exhibited higher quartz content due to alteration of the potash feldspars, migration of the potassium and sodium and liberation of the silica as quartz via the processes of sericitization and silicification. 


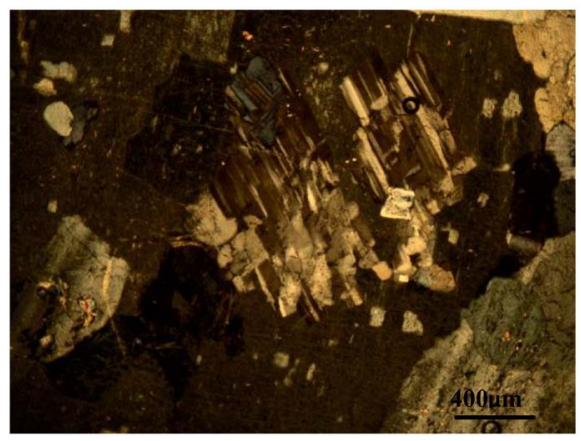

Figure 10. Photomicrographs for El Sela biotite granite showing: Coarse crystal of antiperthite digesting plagioclase with intermittent lamella, CN.

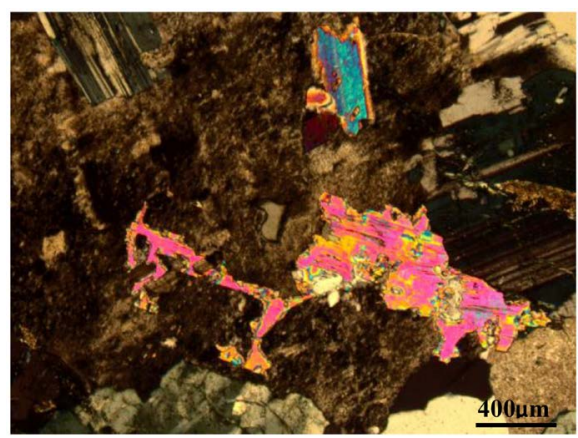

Figure 11. Photomicrograph for El Sela biotite granite showing; Anhedral crystal of perthite corroding muscovite, CN.

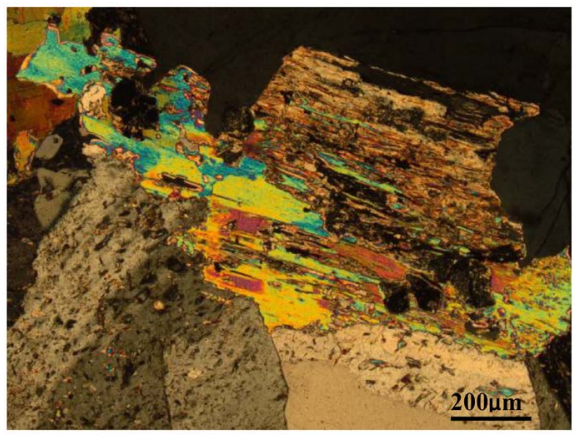

Figure 12. Photomicrographs for El Sela biotite granite showing; Biotite partially altered to muscovite, $\mathrm{CN}$.

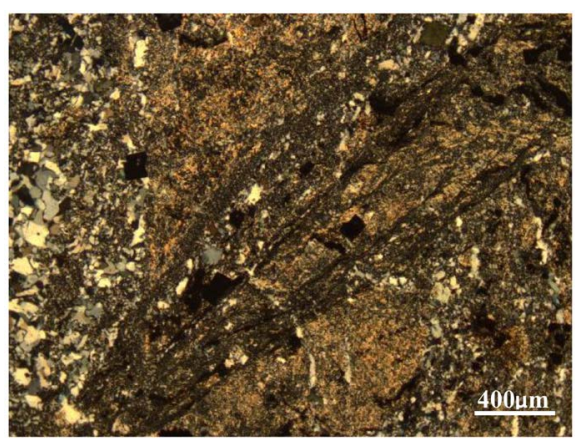

Figure 13. Photomicrograph for El Sela biotite granite showing; Sussiritization and silicification of plagioclase, $\mathrm{CN}$. 


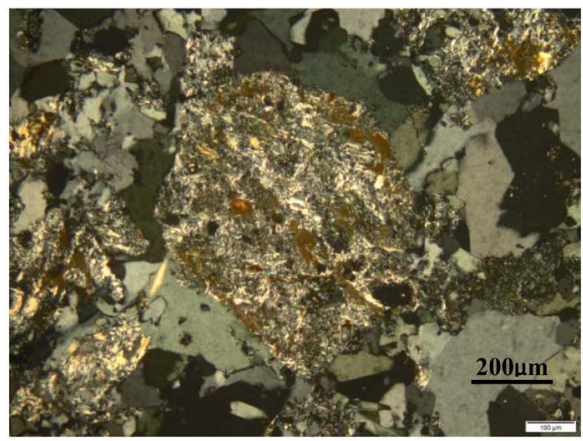

Figure 14. Photomicrographs for El Sela biotite granite showing; Pseudomorph of alkali feldspar sericitization and silicification, CN.

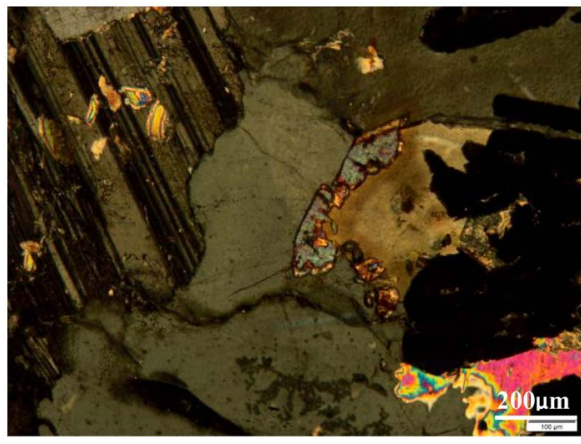

Figure 15. Photomicrograph for El Sela biotite granite showing; Fractured crystal of zircon associating quartz and plagioclase, $\mathrm{CN}$.

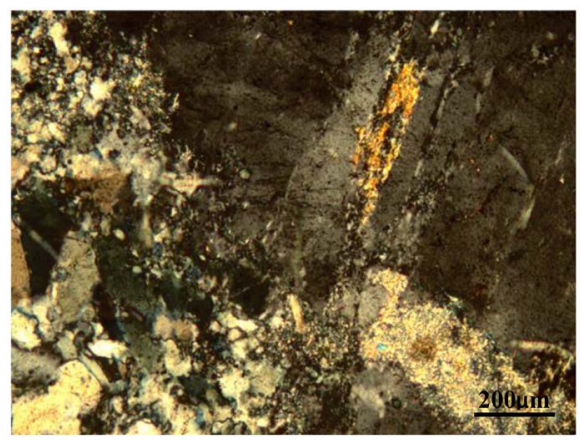

Figure 16. Photomicrographs for El Sela biotite granite showing; Uranophane associating reworked silica along fracture in quartz, $\mathrm{CN}$.

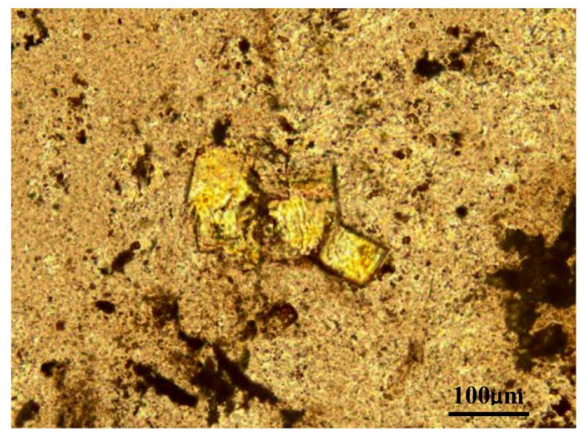

Figure 17. Photomicrograph for El Sela biotite granite showing; Wellformed crystals of autunite included in saussiritized plagioclase, PPL. 


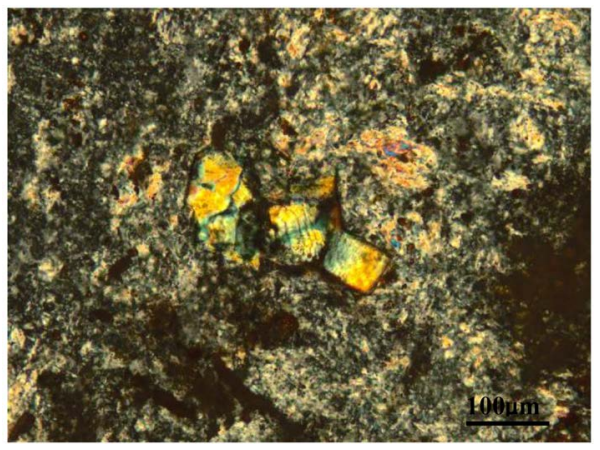

Figure 18. Photomicrographs for El Sela biotite granite showing; Wellformed crystals of autunite included in saussiritized plagioclase, $\mathrm{CN}$.

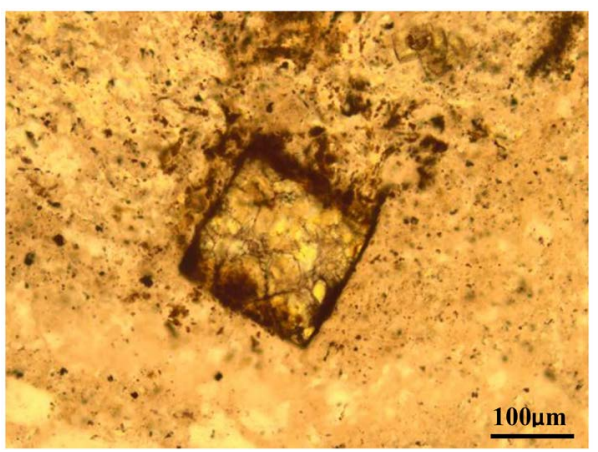

Figure 19. Photomicrograph for El Sela biotite granite: A well-formed crystal of metautunite included in saussiritized plagioclase, PPL.

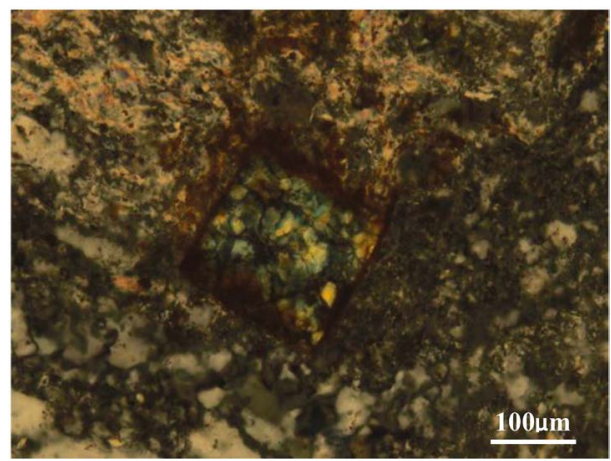

Figure 20. Photomicrographs for El Sela biotite granite: A well-formed crystal of metautunite included in saussiritized plagioclase, $\mathrm{CN}$.

Plotting of the modal analyses (Table 1) on the ternary diagram of Streckeisen (1976) indicated that it is monzogranite that belongs to I-type (Figure 21); originated in the late orogeny by syncollosion tectonic regime (Maniar and Piccoli, 1989) (Figure 22).

\section{Uranium Mineralization in G. El Sela}

Radioelements concentrations measured radiometrically and listed in Table 2. The data exhibited three groups of the samples; the first is the fresh granite with low radioactivity characterized by low concentrations of the uranium (from 8 to 
$15 \mathrm{ppm}$ ) with measurable concentrations of Th (from 22 to $26 \mathrm{ppm}$ ) by low eRa and high $\mathrm{K} \%$ with moderate $\mathrm{eTh} / \mathrm{eU}$ ratio (1.7 to 3.25 ) less than the world ratio (3.5) (Rogers and Adams, 1969) [12]. In contrast, the second group is the altered granite with moderate radioactivity where $\mathrm{U}$-concentration ranges from 76 to $184 \mathrm{ppm}$ and thorium is nearly absent. It is characterized by high eRa and low $\mathrm{K} \%$ with very low eTh/eU ratio $(<0.005)$, without uranium minerals meaning that the second group suffered more decay and enriched by uranium rather than the first group. The third group is the altered granite with anomalous radioactivity that characterized by very high eU-concentrations (2240 and $3725 \mathrm{ppm}$ ) with absence of eTh and K\%.

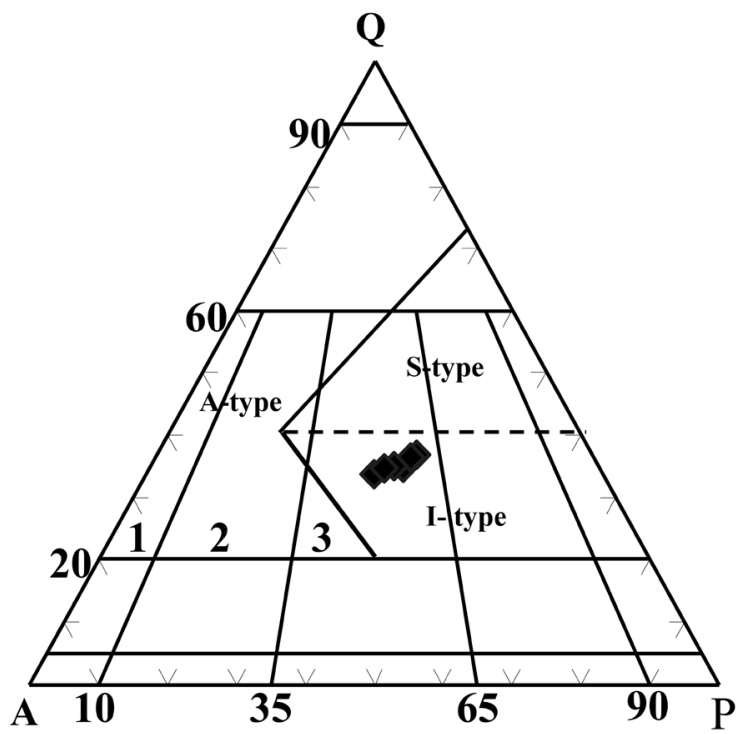

Figure 21. The modal analysis (Streckeisen, 1976) $(1$ = Alkali-feldspar granite, 2 = Syenogranite, 3 = Monzogranite), and type of El Sela granite (Loiselle \& Wones, 1979).

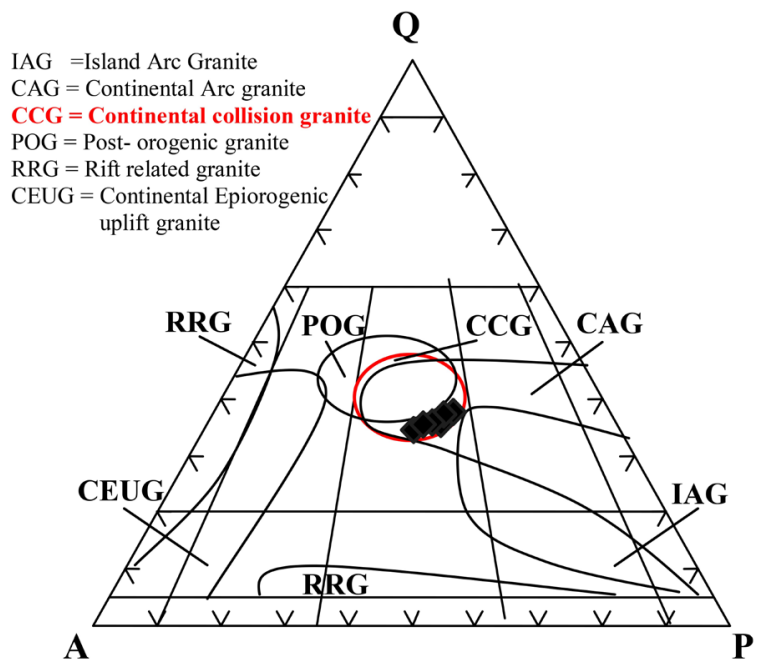

Figure 22. The modal analysis and tectonic setting of El Sela granite (Maniar \& Piccoli, 1989). 
Table 1. Modal analysis for the mineralogical composition of the sheared biotite granite of G. El Sela.

\begin{tabular}{cccccc}
\hline Sample No. & Quartz \% & $\begin{array}{c}\text { Potash } \\
\text { Feldspar \% }\end{array}$ & Plagioclase \% & $\begin{array}{c}\text { Mafic } \\
\text { Minerals \% }\end{array}$ & $\begin{array}{c}\text { Opaque \& } \\
\text { Accessory \% }\end{array}$ \\
\hline ES1 & 35.2 & 29.5 & 31.9 & 2.6 & 0.8 \\
ES2 & 36.5 & 28.5 & 31.6 & 1.5 & 1.9 \\
ES3 & 35.4 & 28.9 & 30.1 & 4.4 & 1.2 \\
ES4 & 34.5 & 26.1 & 34.4 & 4.1 & 0.9 \\
ES5 & 36.2 & 27.4 & 32.8 & 1.6 & 2.0 \\
ES6 & 34.7 & 27.2 & 34.0 & 2.9 & 0.8 \\
Av & $\mathbf{3 5 . 4}$ & $\mathbf{2 7 . 9}$ & $\mathbf{3 2 . 5}$ & $\mathbf{2 . 9}$ & $\mathbf{1 . 3}$ \\
\hline
\end{tabular}

Table 2. Radiometric concentrations of the radioelements in the sheared biotite granite of G. El Sela.

\begin{tabular}{|c|c|c|c|c|c|c|}
\hline & Sample & $\mathrm{eU}(\mathrm{ppm})$ & eTh (ppm) & $\mathrm{eRa}(\mathrm{ppm})$ & $\mathrm{K} \%$ & $\mathrm{eTh} / \mathrm{eU}$ \\
\hline & ES1 & 8 & 26 & 9 & 3.0 & 3.25 \\
\hline Low & ES3 & 8 & 24 & 4 & 3.2 & 3.0 \\
\hline \multirow[t]{3}{*}{ Radioactivity } & $\mathrm{ES} 4$ & 15 & 25 & 10 & 3.85 & 1.7 \\
\hline & ES6 & 11 & 22 & 5 & 4.16 & 2.0 \\
\hline & ES2 & 184 & $\mathrm{Ud}$ & 133 & 1.18 & $<0.005$ \\
\hline Moderate & ES5 & 180 & Ud & 151 & 1.06 & $<0.005$ \\
\hline \multirow[t]{2}{*}{ Radioactivity } & ES8 & 76 & 1 & 66 & 1.35 & 0.01 \\
\hline & ES9 & 163 & Ud & 117 & 1.52 & $<0.006$ \\
\hline Anomalous & ES10 & 2240 & Ud & 1390 & $\mathrm{Ud}$ & $<0.001$ \\
\hline Radioactivity & ES11 & 3725 & Ud & 1525 & $\mathrm{Ud}$ & $<0.001$ \\
\hline
\end{tabular}

Detection limit $=1 \mathrm{ppm}$ Ud (undetected) $\leq 1$.

The highest contents of $\mathrm{K} \%$ recorded in the less altered samples $(3.0 \%$ $4.16 \%)$, decreases in the altered samples of the second group $(1.06 \%-1.52 \%)$ and completely absent in the anomalous samples with intensive alteration (Table 2). It decreases with increasing the U-concentration as the alteration increases where the $\mathrm{K}^{+}$ions of the potash feldspars (the main source for $\mathrm{K}^{40}$ ), liberated and escape with the meteoric water during the processes of alteration excluding the secondary quartz (silicification) according to the equations of Walther (2005) [13].

For sericitization:

$$
\begin{array}{lcc}
3 \mathrm{KAlSi}_{3} \mathrm{O}_{8}+2 \mathrm{H}^{+} \rightleftarrows \underset{\mathrm{KAl}_{3} \mathrm{Si}_{3} \mathrm{O}_{10}(\mathrm{OH})_{2}}{ }+\underset{\text { Sericite }}{6 \mathrm{SiO}_{2}}+2 \mathrm{~K}^{+} \\
\text {K-feldspar } & \text { Quartz }
\end{array}
$$

For kaolinization:

$$
\begin{aligned}
& 2 \mathrm{KAlSi}_{3} \mathrm{O}_{8}+2 \mathrm{H}^{+}+\mathrm{H}_{2} \mathrm{O} \underset{\text { K-feldspar }}{\stackrel{\mathrm{Al}_{2} \mathrm{Si}_{2} \mathrm{O}_{5}(\mathrm{OH})_{4}}{\text { Kaolinite }}+4 \mathrm{SiO}_{2}+2 \mathrm{~K}^{+}} \text {Quartz }
\end{aligned}
$$

El Sela anomalous granite dominated by the minerals of autunite group as uranyl phosphate minerals namely; autunite, meta-autonite, meta-natroautunite and phurcalite in addition to rare crystals of uranophane. The prefix (meta-)indicated that the mineral is dehydrated. 


\subsection{Meta-Autunite $\left(\mathrm{Ca}\left(\mathrm{UO}_{2}\right)_{2}\left(\mathrm{PO}_{4}\right)_{2} \cdot 2-6 \mathrm{H}_{2} \mathrm{O}\right)$}

It is the hydrous calcium-uranium phosphate mineral characterized by canary yellow color and translucent appearance with waxy luster; it crystallizes in the tetragonal system with dipyramidal form (Figure 23). It is very soft and brittle with corroded boundaries. It could be identified by XRD giving its characteristic diffractogram (Figure 24)

The crystals examined by ESEM exhibiting the dipyramidal form (Figure 25). The EDX analysis confirmed the main constituents as Ca (7.1 Wt\%), U (58.09 $\mathrm{Wt} \%)$ and $\mathrm{P}(5.24 \mathrm{Wt} \%)$, while $\mathrm{Na}$ and $\mathrm{K}$ present as traces (1.04 \& $0.91 \mathrm{Wt} \%)$ indicating that they may be substitutable for calcium (Figure 26).

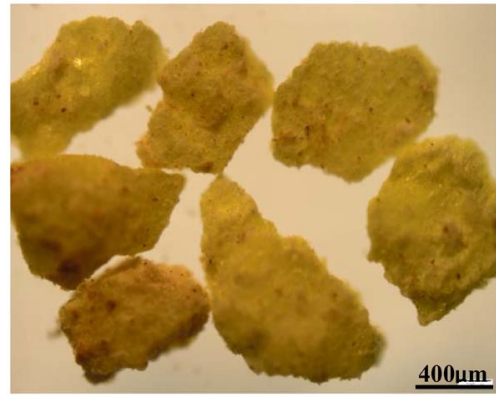

Figure 23. Stereophotograph of metautunite.

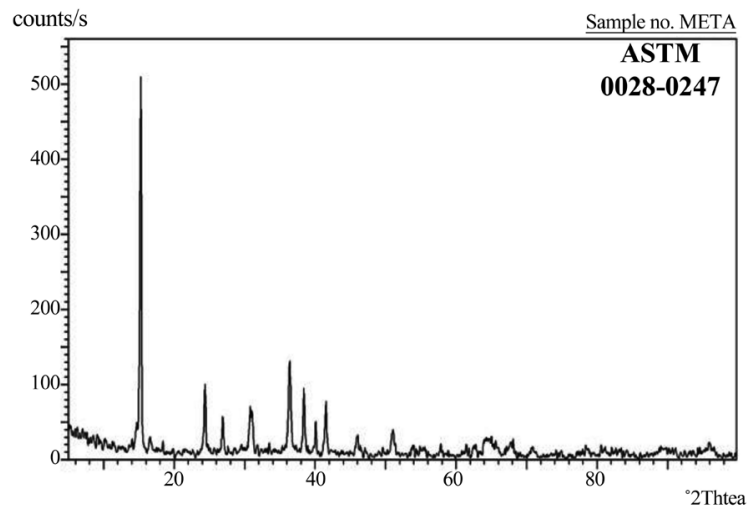

Figure 24. XRD diffractogram of metautunite.

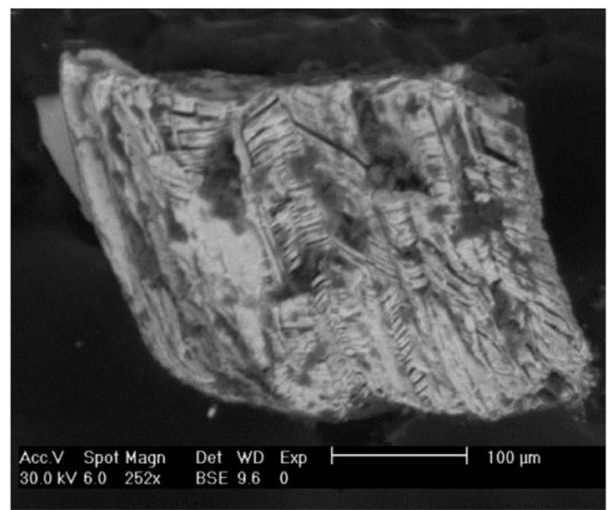

Figure 25. BSE image of metautunite. 


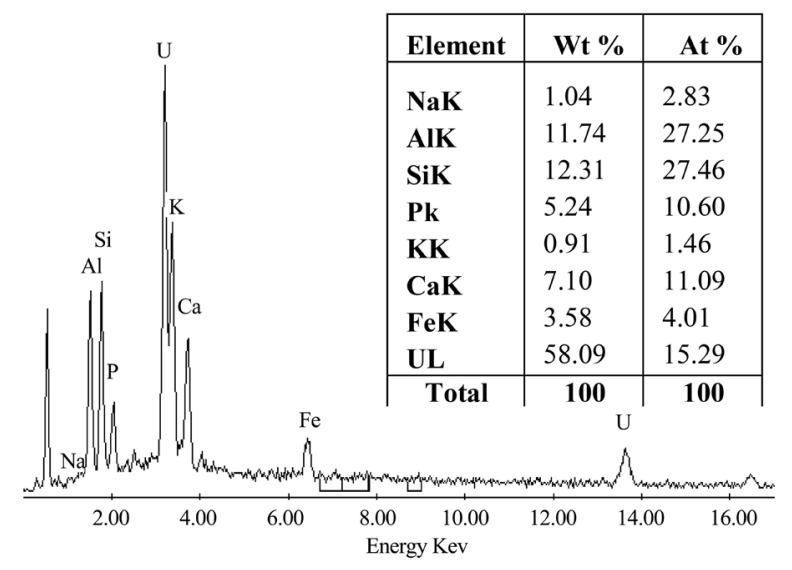

Figure 26. ESEM spectrograph of metautunite.

\subsection{Meta-Natroautunite $\left(\mathrm{Na}\left(\mathrm{UO}_{2}\right)\left(\mathrm{PO}_{4}\right)\left(\mathrm{H}_{2} \mathrm{O}\right)_{3}\right)$}

It is the sodium-rich member of the autunite group. Originally published by Chernikov et al., (1957) [14] as "sodium autunite", but changed in the same year by the authors to "natroautunite". The mineral renamed as "meta-natroautunite" by Chernikov and Organova (1994) [15] due to its dehydrated character.

Microscopic investigation revealed that the mineral is characterized by lemon yellow color with vitreous to waxy luster. The mineral is present as soft tablets with low hardness and relative transparency. Mills et al., (2012) [16] recognized its crystal system as tetragonal occurring in flaky forms as sheets and tablets with sharp faces and cleavage (Figure 27). The mineral is surly identified by XRD technique giving its characteristic diffractogram (Figure 28).

The composition of meta-natroautunite clarified by the environmental scanning microscope (ESEM) (Figure 29), indicating that the mineral compose of sodium, uranium and phosphorous with traces of alumina (1.2 Wt\%), silica (2.2 $\mathrm{Wt} \%)$, potassium $(1.12 \mathrm{Wt} \%)$, calcium $(1.0 \mathrm{Wt} \%)$, iron $(0.02 \mathrm{Wt} \%)$ and lead (0.38 Wt\%) (Figure 30).

\subsection{Phurcalite $\left(\mathrm{Ca}_{2}\left(\mathrm{UO}_{2}\right)_{3} \mathrm{O}_{2}\left(\mathrm{PO}_{4}\right)_{2} \cdot 7\left(\mathrm{H}_{2} \mathrm{O}\right)\right.$}

Phurcalite is secondary uranium mineral that composed of calcium-uraniumphosphate. Microscopic investigation revealed that it is present as brittle crystals with canary yellow color and earthy luster (Figure 31). Its crystal system is orthorhombic with dipyramidal form; it could be examined by XRD and exhibited its characteristic diffractogram (Figure 32).

BSE image clarified the brittle appearance (Figure 33) and the mineral composition confirmed by EDX analysis by the electron scanning microscope. The spectrograph clarified that the main mineral composition is associated with $\mathrm{Ti}$ and Fe. The EDX analysis indicated appreciable content of $\mathrm{Ti}(1.78 \mathrm{Wt} \%)$ and $\mathrm{Fe}$ (7.85 Wt\%) beside the main constituents, calcium (5.24 Wt\%), uranium (52.12 $\mathrm{Wt} \%$ ) and phosphorous (0.92 Wt\%) (Figure 34), suggesting that the mineral may be derived from calcic uranyl phosphate mineral may be autunite. 


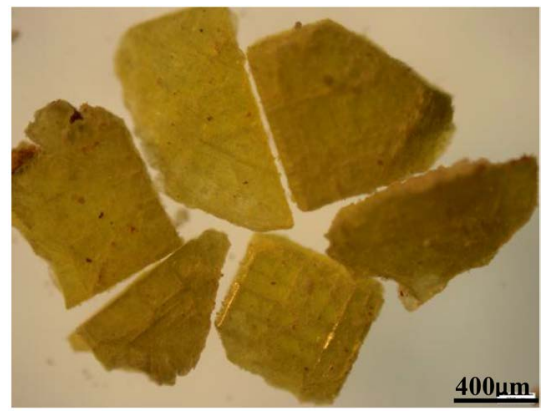

Figure 27. Stereophotograph of meta-natroautunite.

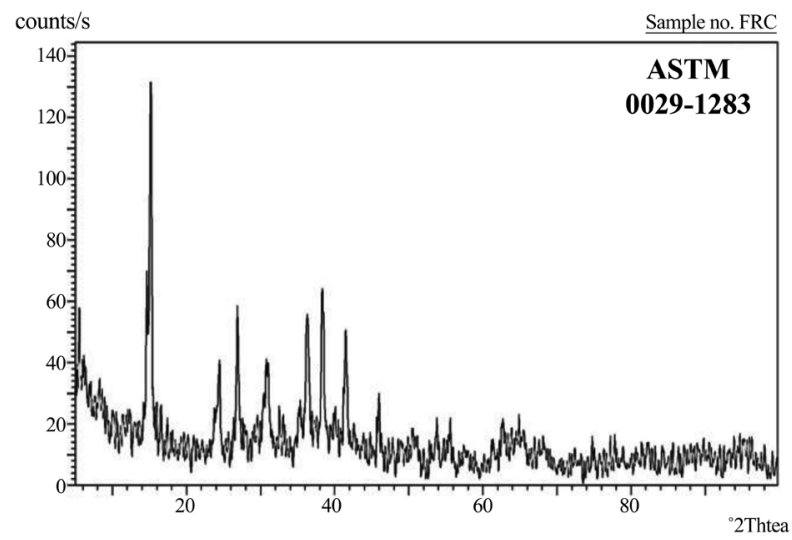

Figure 28. XRD diffractogram of meta-natroautunite.

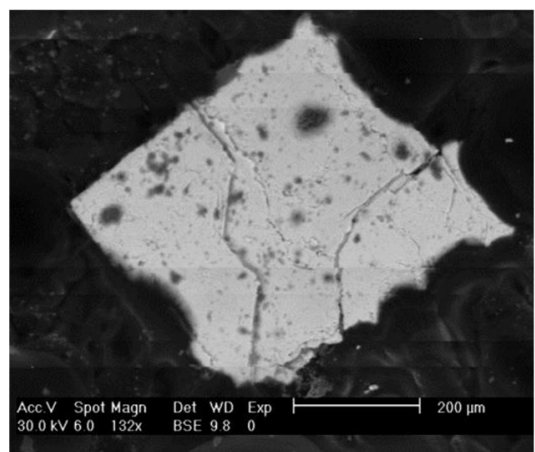

Figure 29. BSE image of meta-natroautunite.

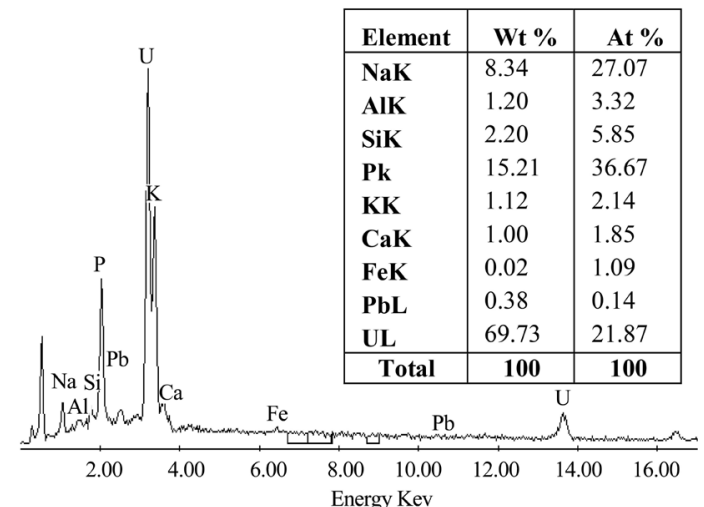

Figure 30. ESEM spectrograph of meta-natroautunite. 


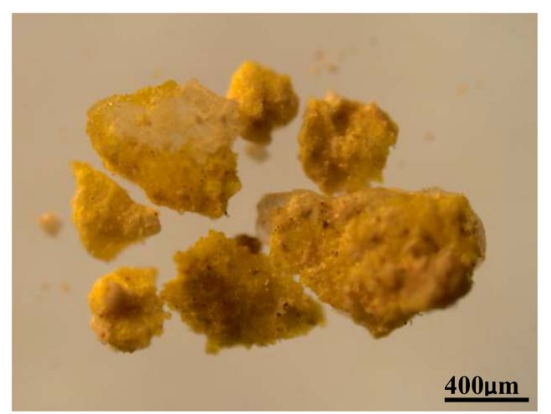

Figure 31. Stereophotograph of phurcalite.

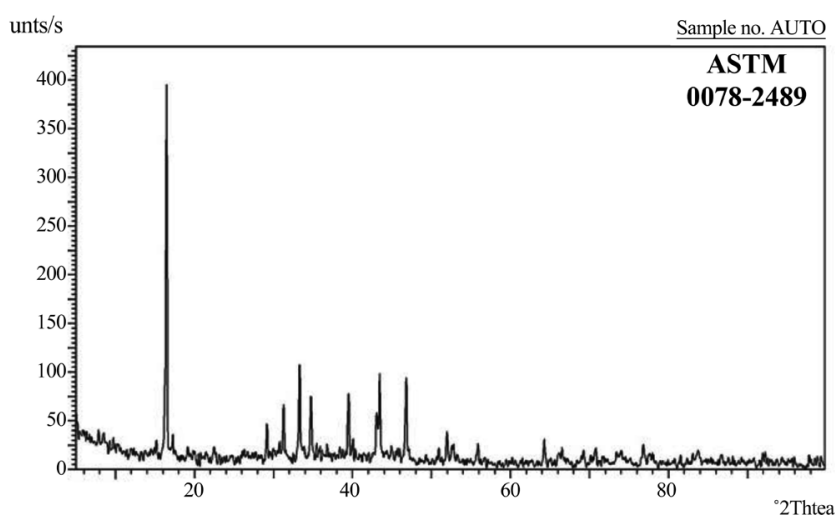

Figure 32. XRD diffractogram of phurcalite.

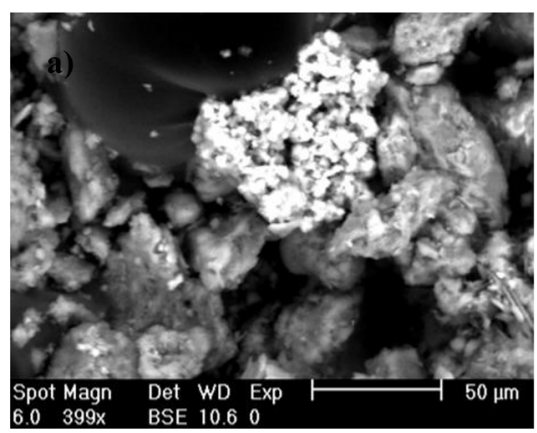

Figure 33. BSE image of phurcalite.

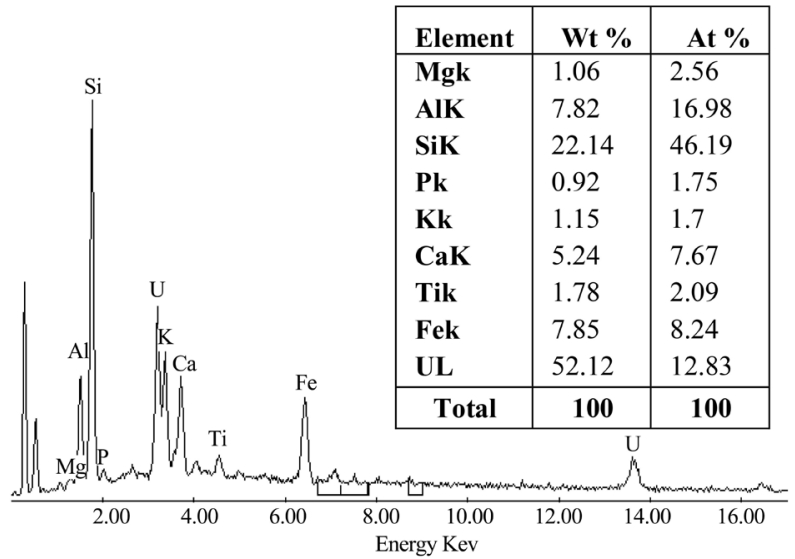

Figure 34. ESEM spectrograph of phurcalite. 


\subsection{Uranophane $\left(\mathrm{Ca}\left(\mathrm{UO}_{2}\right)_{2} \mathrm{SiO}_{3}(\mathrm{OH})_{2} \cdot 5\left(\mathrm{H}_{2} \mathrm{O}\right)\right.$ and Fluorite $\left(\mathrm{CaF}_{2}\right)$}

Uranophane found as rare aggregates of needle-like crystals characterized by bright yellow color (Figure 35) with monoclinic crystal system. Fluorite present as fine cubic crystals with violet color $(1.2 \mathrm{~mm})$ found as well-formed crystals associating the main constituents of the rock suggesting the magmatic origin (Figure 36$)$. It is also found as minute crystals $(30 \mu \mathrm{m})$ associating the uranophane that may be originated by the hydrothermal solutions (Figure 37).

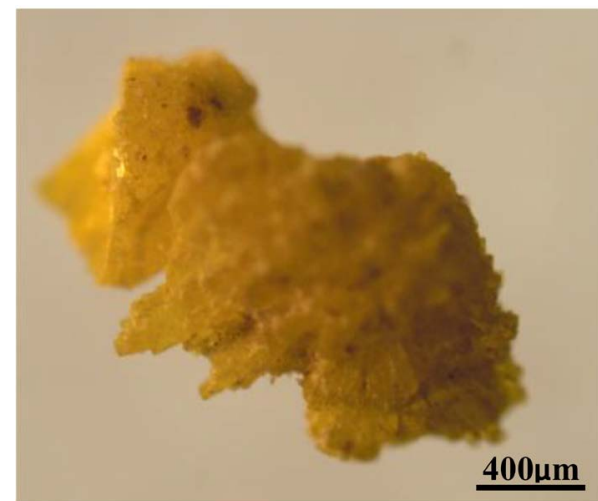

Figure 35. Stereophotograph showing aggregate of needle-like crystals of uranophane.

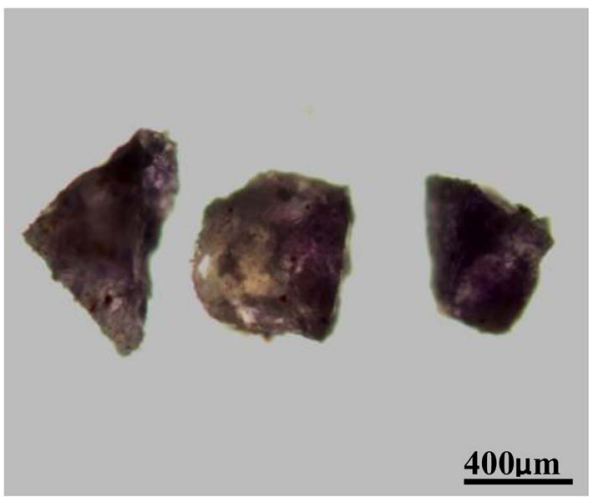

Figure 36. Stereophotograph showing cubic crystals of violet fluorite.

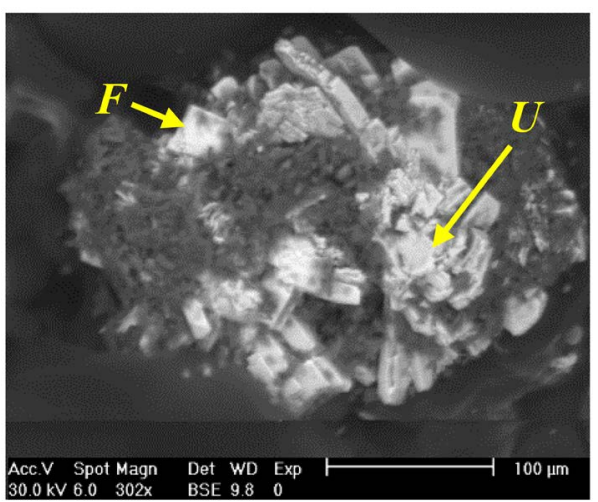

Figure 37. BSE image of uranophane (U) and fluorite (F). 
The spectrographs illustrated the composition of uranophane (Figure 38) and fluorite (Figure 39). The EDX analysis of uranophane clarified presence of fluorine $(4.81 \mathrm{Wt} \%)$, alumina $(7.64 \mathrm{Wt} \%)$, phosphorous $(4.0 \mathrm{Wt} \%)$ and iron $(2.39$ $\mathrm{Wt} \%)$ besides the main constituents; calcium (40.35 Wt\%), uranium (28.44 $\mathrm{Wt} \%$ ) and silica (12.38 Wt\%), suggesting that uranophane may be created from the autunite minerals. The analysis of the associated fluorite characterized by traces of alumina $(1.62 \mathrm{Wt} \%)$ and silica $(2.45 \mathrm{Wt} \%)$ beside the main constituents; fluorine $(43.7 \mathrm{Wt} \%)$ and calcium $(52.23 \mathrm{Wt} \%)$.

\section{Paragenesis of the Autunite-Group Minerals}

El Sela granite encloses a series of uranyl phosphate minerals (autunite group) with paragenetic sequence starting by autunite (calcic uranyl phosphate) and ends by meta-natroautunite (sodic uranyl phosphate). Meta-autunite recorded as a transitional mineral composed of sodic-calcic uranyl phosphate where $\mathrm{Na}^{+}$ induced from the altered feldspars and mica minerals. Presence of fluorite in El Sella granite prove that it is derived from high volatile-magma (Kolsov, 2009) [17] suitable for crystallization of hydrous uranyl minerals such as autunite $\left(\mathrm{Ca}\left(\mathrm{UO}_{2}\right)_{2}\left(\mathrm{PO}_{4}\right)_{2} \cdot 10-12\left(\mathrm{H}_{2} \mathrm{O}\right)\right)$. An advanced process of dehydration accompanies the process of mineral transformation from autunite to meta-natroautonite leading to formation of the anhydrous uranyl phosphate minerals $\left(\mathrm{Na}\left(\mathrm{UO}_{2}\right)\left(\mathrm{PO}_{4}\right)\left(\mathrm{H}_{2} \mathrm{O}\right)_{3}\right)$.

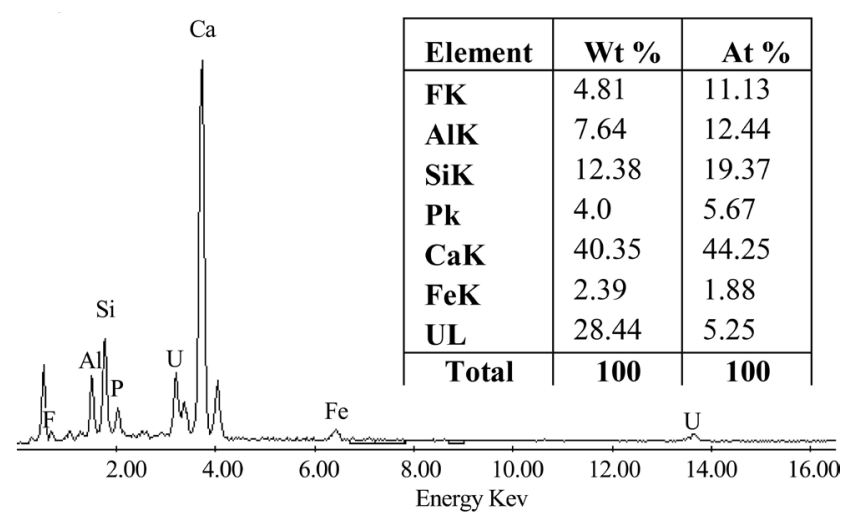

Figure 38. ESEM spectrograph of uranophane.

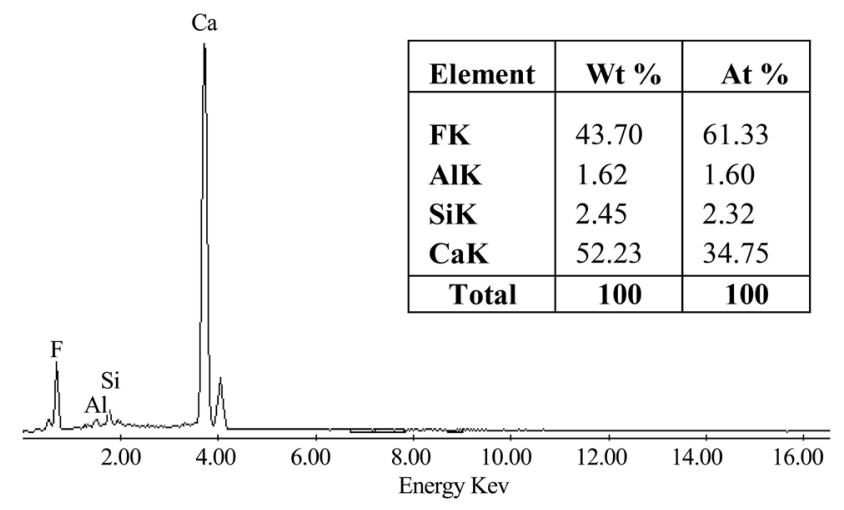

Figure 39. ESEM spectrograph of fluorite. 
Phurcalite is a secondary mineral with chemical formula characterized by more oxygen and less $\mathrm{H}_{2} \mathrm{O}$ rather than autunite indicating that phurcalite formed by oxidation and dehydration of autunite. It is mostly present in the fractures in El Sela granite associating amorphous silica indicating that the mineral may be formed by post-magmatic processes with high oxygen and low temperature.

Uranophane found as rare aggregate of needle-like crystals. It is the final mineral in the series of uranium minerals (secondary uranyl silicate mineral) that formed by thermal confusion of autunite with the silica. Association of uranophane with the reworked silica (see Figure 16) and presence of phosphorous in the EDX analysis of uranophane (4.0 Wt\%), may enhance the assumption of confusion according to the equation of Langmuir (1977) [18]. The resultant phosphoric acid transported by the meteoric water causing enrichment of the sedimentary rocks y phosphorous.

$$
\begin{aligned}
& \mathrm{Ca}\left(\mathrm{UO}_{2}\right)_{2}\left(\mathrm{PO}_{4}\right)_{2}+2 \mathrm{H}_{4} \mathrm{SiO}_{4} \rightleftarrows \mathrm{Ca}\left(\mathrm{UO}_{2}\right)_{2}\left(\mathrm{SiO}_{3} \mathrm{OH}\right)_{2}+2 \mathrm{H}_{2} \mathrm{PO}_{4}^{-}+2 \mathrm{H}^{+} \\
& \text {autunite Quartz uranophane phosphoric acid }
\end{aligned}
$$

Presence of the three groups of the granite with three levels of radioactivity accompanied with disappearance of the uranium minerals in the second group and appearance of autunite minerals in the third group is indicative to presence of two main types of alteration in G. El Sela. The first is the thermal alteration (saussiritization, sericitization, kaolinization, silicification and hematization) that controlled by the temperature of the hydrothermal solutions proceeding on the feldspars causing liberation and mobility of uranium ions. The second is the chemical transformation (oxidation, dehydration, ion substitutions and confusion) that controlled by the physicochemical conditions and the heating temperature that generated during the plates collision causing formation of the secondary uranium minerals and transformation from a state to another.

\section{Discussion and Conclusions}

El Sela granitic pluton crops in the South Eastern Desert are two parts: the northern part is intensively sheared divided by ENE-WSW major fault superimposed by NNW-SSE and parallel fault set represents the main shearing zone. It is described as biotite granite and categorized as monzo-granite composed of plagioclase, potash feldspars quartz, and mica minerals (biotite and muscovite). It is I-type granite originated in the syncollision tectonic setting by attenuation of the earth crust.

The fresh samples in the studied shearing zone are characterized by low level of radioactivity, while the samples approaching the faults are moderately radioactive (from 76 to184 ppm) or anomalous (2240 and $3275 \mathrm{ppm}$ ) with nearly complete absence of the thorium content. Mineralogical studies indicate that the radioactive minerals are mainly uranium phosphate minerals of the autunite group recognized as metautunite, meta-natroautunite and phurcalite with rare crystals of uranophane. 


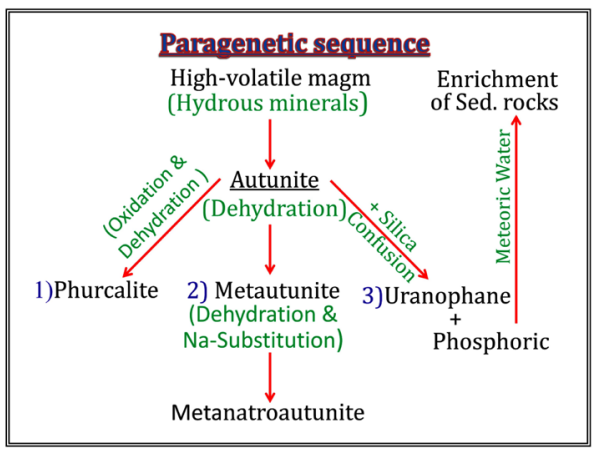

Figure 40. Flow sheet proposed for paragenesis of autunite group minerals.

Paragenesis of these minerals indicates that they represent a series of uranyl phosphate minerals (autunite group) with paragenetic sequence starting by autunite (calcic uranyl phosphate) and ends by meta-natroautunite (sodic uranyl phosphate). Meta-autunite is recorded as a transitional mineral composed of sodic-calcic uranyl phosphate where $\mathrm{Na}^{+}$is induced from the altered feldspars and mica minerals. Presence of fluorite in El Sela granite proves that it is derived from high volatile-magma suitable for crystallization of hydrous uranyl minerals such as autunite $\left(\mathrm{Ca}\left(\mathrm{UO}_{2}\right)_{2}\left(\mathrm{PO}_{4}\right)_{2} \cdot 10-12\left(\mathrm{H}_{2} \mathrm{O}\right)\right)$. A progressive process of dehydration accompanies the process of mineral transformation from autunite to meta-natroautunite leading to formation of the anhydrous uranyl minerals $\left(\mathrm{Na}\left(\mathrm{UO}_{2}\right)\left(\mathrm{PO}_{4}\right)\left(\mathrm{H}_{2} \mathrm{O}\right)\right)$. Phurcalite is secondary mineral with chemical formula characterized by more oxygen and less $\mathrm{H}_{2} \mathrm{O}$ rather than autunite indicating that phurcalite is formed by oxidation and dehydration of autunite. Uranophane is created by thermal confusion of autunite with the silica; proved by presence of amorphous silica (microscopically) and phosphorous in the EDX analysis of this mineral. The confusion temperature results from the hydrothermal solutions responsible for production of fluorite associating the uranophane and reworking of silica (Figure 40).

The study finished to the presence of two main types of alteration corresponding to the two high levels of radioactivity (moderate and anomalous). The first is the thermal alteration responsible for decomposition of the feldspars (saussiritization, sericitization, kaolinization, silicification and hematization) and the second is the chemical transformation (oxidation, dehydration, ion substitutions and confusion) responsible for formation of the secondary uranyl phosphate minerals. The temperature needed for the thermal alteration is sourced by the hydrothermal solutions, while the temperature needed for the uranium minerals transformation may be generated during the episode of the continental plate collision (syncollision).

\section{Acknowledgements}

I would like to express my gratitude to my colleagues in the Egyptian Nuclear Materials Authority (NMA). The author is deeply indebted to Prof. Dr. Sayed 
Omar for his field facilities and picking the samples and Prof. Dr. El Sayed El Sawy, the head of XRD Lab. The author is also grateful to the members ESEM lab especially Prof. Dr. Gehan Ali.

\section{Conflicts of Interest}

The author declares no conflicts of interest regarding the publication of this paper.

\section{References}

[1] Ali, K.G. (2011) Structural Control of El Sela Granites and Associated Uranium Deposits, Southern Eastern Desert, Egypt. Arabian Journal of Geosciences, 6, 1753-1767. https://doi.org/10.1007/s12517-011-0489-y

[2] Ali, M.A. and Lentz, D.R. (2011) Mineralogy, Geochemistry and Age Dating of Shear Zone-Hosted Nb, Ta, Zr, Hf, Th, U-Bearing Granitic Rocks in the Ghadir and El Sella Areas, South Eastern Desert, Egypt. Chinese Journal of Geochemistry, 30, 453-478. https://doi.org/10.1007/s11631-011-0531-5

[3] Mira, H.I. and Ibrahim, T. (2011) Mineralogical and Geochemical Evidence for Tetravalent Uranium Biomineralization within El Sela Weathered Granite, South Eastern Desertn, Egypt. Ann. Geo. Surv. Egypt, 41, 417-430.

[4] Fawzy, M.M. (2012) Geological and Upgrading Studies for El Sela Uranium Deposits, South Eastern Desert, Egypt, Ph.D. Thesis, Faculty of Science, Helwan University, Egypt, 70-76.

[5] Shalan, A.S. (2012) Mineralogical and Geochemical Characteristics of Altered Rocks in Gabal El Sela Granite with Special Emphasis on the Genesis of Uranium Mineralization, South Eastern Desert, Egypt. M.Sc., Al-Azhar University, Cairo, 90-125.

[6] NMA (2013) El Sela Development Project, Southern Eastern Desert, Egypt. Internal Report (ESDP 012-013).

[7] Anwar, E. (2015) Contribution to the Mineralogy of Rl Sela Uraniferous Shear Zone, South Eastern Desert, Egypt. Al Azhar Buletin of Science, 26, 51-59. https://doi.org/10.21608/absb.2015.22623

[8] Sadek, A.A. (2017) Mineralogy, Radioactivity and Fluid Inclusion Studies of Gabal El Sela Granite South Eastern Desert, Egypt. Egyptian Journal of Geology, 61, 83-102.

[9] Streckeisen, A.L. (1976) To Each Plutonic Rock Its Proper Name. Earth-Science Reviews, 12, 1-33. https://doi.org/10.1016/0012-8252(76)90052-0

[10] Loiselle, M.C. and Wones, D.R. (1979) Characteristics and Origins of Anoroginic Granite. Geological Society of America, Abstract with Program 11, 468.

[11] Maniar, P.D. and Piccoli, P.M. (1989) Tectonic Discrimination of Granitoids. Geological Society of America Bulletin, 101, 635-643. https://doi.org/10.1130/0016-7606(1989)101<0635:TDOG>2.3.CO;2

[12] Rogers, J.J.W. and Adams, J.S.S. (1969) Uranium. In: Wedepohl, K.H., Ed., Handbook of Geochemistry, Vol. 4, Springer-Verlag, New York, 92.

[13] Walther, J.V. (2005) Essentials of Geochemistry. Jones and Bartlett, Burlington, 704.

[14] Chernikov, A.A., Krutetskaya, O.V. and Organova, N.I. (1957) Natroautunite. Soviet Journal of Atomic Energy, 3, 901-905. https://doi.org/10.1007/BF01480073

[15] Chernikov, A.A. and Organova, N.I. (1994) Natroautunite and Metanatroautunite. Transactions of the Russian Academy of Sciences, 341A, 109-113. 
[16] Mills, S.J., Birch, W.D. and Kampf, A.R. (2012) The Crystal Structure of Metanatroautunite, $\mathrm{Na}\left[\left(\mathrm{UO}_{2}\right)\left(\mathrm{PO}_{4}\right)\right]\left(\mathrm{H}_{2} \mathrm{O}\right)_{3}$, from the Lake Boga Granite, Victoria, Australia. American Mineralogist, 97, 735-738. https://doi.org/10.2138/am.2012.3866

[17] Kozlov, V.D. (2009) Rare-Earth Elements as Indicators of Ore Sources and Degree of Differentiation and Ore Potential of Rare Metal Granite Intrusions, Eastern Transbaikalia. Russian Geology and Geophysics, 50, 29-42. https://doi.org/10.1016/j.rgg.2008.06.015

[18] Langmuir, D. (1977) Uranium Solution-Mineral Equilibria at Low Temperatures with Application to Sedimentary Ore Deposits. US Department of Energy, 24-160. 